\title{
Identification by PCR of genes encoding multiple response regulators
}

\author{
Françoise Morel-Deville, ${ }^{1}$ S. Dusko Ehrlich² and Patrice Morel ${ }^{2}$
}

Laboratoire de Recherche sur la Viande ${ }^{1}$ and Laboratoire de Génétique Microbienne², Institut National de la Recherche Agronomique, Domaine de Vilvert, 78352 Jouy en Josas Cedex, France
Author for correspondence: Patrice Morel. Tel: + 331346525 20. Fax: + 33134652521. e-mail: pmorel@biotec.jouy.inra.fr
Keywords: receiver module, response regulator, signal transduction, two-component systems, PCR degenerate primer

\section{INTRODUCTION}

It is well known that bacteria are able to sense and to respond to a variety of environmental stimuli (for reviews see Parkinson, 1993; Hoch \& Silhavy, 1995). The transduction of the signals to the target proteins that effect the appropriate response to these stimuli often involves two-component regulatory proteins, i.e. sensor kinases and response regulators (for reviews see Stock et al., 1989a, 1990; Parkinson \& Kofoid, 1992). The sensor kinases, which are often anchored to the cytoplasmic membrane, monitor some environmental parameters, whereas the cytoplasmic response regulators mediate an adaptive response which is usually a change in gene expression or in cell behaviour. Communication between the sensors and their associate response regulators involves phosphorylation and dephosphorylation reactions. The frame of the mechanism of sensor/ regulator systems therefore appears to be simple. However, sophisticated devices ensuring that the output responses are smoothly graded with stimulus intensity have been discovered (for review see Hoch \& Silhavy, 1995).

Sensor and response regulator proteins contain characteristic domains, termed transmitters and receivers, respectively. They are combined with input and output domains and can be arranged in different configurations to build signalling circuits (for reviews see Stock et al., 1989a; Parkinson \& Kofoid, 1992; Parkinson, 1993; Alex \& Simon, 1994). In the simplest circuit, the sensors contain a C-terminal transmitter module preceded by an $\mathrm{N}$-terminal signal-input domain; response regulators contain an $\mathrm{N}$-terminal receiver module followed by a Cterminal signal-output domain. The transmitter modules are about 240 aa in length, with several short stretches of amino acids common to all members of the sensor kinase family. In particular, an invariant autophosphorylated histidine is often located near the $\mathrm{N}$ terminus of the modules (Parkinson, 1993; Stock et al., 1995). The receiver modules are roughly 120 aa in length. They also share characteristic sequence features, among them an invariant aspartate residue located near the centre $(\mathrm{Pao}$ \& Saier, 1995; Volz, 1995). Phosphorylation of this particular aspartate residue by the phospho-histidine of its cognate sensor kinase leads to conformational changes of the receiver module which presumably go with the modification of the associated output domain activity (i.e. transcriptional activation) and results in the appropriate cellular response (Falke et al., 1995). Hybrid or unorthodox sensors have also been described (Parkinson \& Kofoid, 1992). In these cases, input and 
transmitter domains and the receiver module are associated in the same protein.

To date, members of the sensor/regulator families have been described in more than 50 different bacterial species. Some have also been discovered in several eukaryotic organisms, including Neurospora crassa, Saccharomyces cerevisiae, Arabidopsis thaliana and Dictyostelium discoideum (for reviews see Alex \& Simon, 1994; Chang \& Meyerowitz, 1994; Appleby et al., 1996) and we infer that such systems are probably ubiquitous in most living organisms. However, none has been found in the methanogenic archaeon Methanococcus jannaschii (Bult et al., 1996). Interestingly, the number of bacterial two-component systems appears to vary greatly from one bacterial species to another. For example, in Haemophilus influenzae Rd, only five examples of these systems have been identified upon sequencing of its entire genome (Fleischmann et al., 1995), whereas in Escherichia coli, more than 20 different adaptive response systems have been identified so far (Nagasawa et al., 1993). The evolutionary development of this extensive set of related proteins may have occurred through horizontal transmission (Parkinson \& Kofoid, 1992). The hypothesis that all response regulator domains share a common structure is well substantiated (Volz, 1993, 1995; Pao \& Saier, 1995).

In this work, multiple sequence alignments of over 100 receiver modules of known bacterial response regulators allowed us to define degenerate oligonucleotide primers corresponding to two stretches of highly conserved amino acid residues. Using PCR, we developed a simple and powerful method for isolating genes encoding response regulators in bacteria. Specific amplification products were obtained in 12 distinct species of either Gram-positive or Gram-negative bacteria. Previously identified response regulator genes as well as new ones were cloned. One previously unknown response regulator gene was isolated from $E$. coli, seven from Agrobacterium tumefaciens, three from Bacillus subtilis and four from Lactobacillus bulgaricus. This illustrates the usefulness of this approach in isolating new response regulator genes involved in yet unknown environmental adaptive responses.

\section{METHODS}

Strains and plasmids. Bacterial strains used in this study were E. coli TG1 (Biolabs) and HVC45 (laboratory collection), A. tumefaciens LBA4301 (plasmid-free), Erwinia amylovora, Pantoea citrea $1056^{\mathbf{R}}$, Xanthomonas malvacearum (all from C. I. Kado, UC Davis, CA), B. subtilis SB202 (laboratory collection), Clostridium acetobutylicum NCIB8052 (M. Young, University of Wales, Aberystwyth), Enterococcus faecalis (R. Novick, New York University Medical Center), Lb. bulgaricus CNRZ 777 (from the CNRZ collection), Lactobacillus sake 23K (plasmid-free; laboratory collection), Lactococcus lactis subsp. lactis IL1403 (plasmid-free; M. C. Chopin, INRA, Jouy-en-Josas) and Staphylococcus aureus RN450 (R. Novick). Phagemid pBluescript II SK+ was from Stratagene. (a) \begin{tabular}{lllll}
\multicolumn{2}{c}{$D D$ box } & & & \\
$\mathrm{I}_{35}$ & $\mathrm{~V}_{68}$ & $\mathrm{D}_{68}$ & $\mathrm{D}_{97}$ & $\mathrm{D}_{28}$ \\
$\mathrm{~V}_{32}$ & $\mathrm{I}_{13}$ & $\mathrm{E}_{31}$ & $\mathrm{X}_{5}$ & $\mathrm{E}_{27}$ \\
$\mathrm{~L}_{29}$ & $\mathrm{~A}_{13}$ & $\mathrm{X}_{3}$ & & $\mathrm{H}_{22}$ \\
$\mathrm{X}_{6}$ & $\mathrm{X}_{8}$ & & & $\mathrm{~N}_{12}$ \\
& & & & $\mathrm{X}_{15}$
\end{tabular}

(b)

5. ECoRI

C. GGA.ATT.ST,

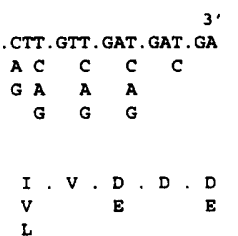

K box

$\begin{array}{lllll}G_{89} & A_{85} & D_{38} & D_{61} & Y_{62} \\ X_{13} & M_{6} & Y_{8} & G_{24} & F_{24} \\ & X_{11} & L_{8} & X_{17} & X_{16} \\ & & S_{7} & & \\ & & F_{6} & & \\ & & X_{35} & & \end{array}$

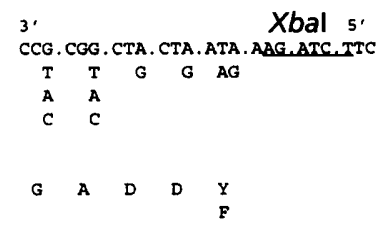

Fig. 1. Receiver module of response regulators. (a) Redundancies of amino acids in the DD and $K$ boxes. $X$ corresponds to any amino acid. (b) Design of the degenerate oligonucleotide primers used in PCR amplifications. The consensus amino acids upon which the primers are based are indicated. Positions of the EcoRI and Xbal restriction sites included at the $5^{\prime}$ ends of the coding strand primer and the complementary strand primer, respectively, are shown.

Standard DNA procedures. Restriction enzymes, ligase and polymerase were purchased from commercial sources and were used according to the suppliers' recommendations. Chromosomal DNA from various bacterial species was extracted as described by Sambrook et al. (1989), Duwat et al. (1992) and Kado et al. (1972). Plasmid preparation and analysis, and preparation and transformation of $E$. coli competent cells were carried out according to standard procedures (Sambrook et al., 1989).

Oligonucleotide PCR primers. The degenerate ssDNA oligonucleotide primers were selected from two highly conserved amino acid stretches in the receiver modules of already published response regulators, i.e. the $\mathrm{DD}$ and $\mathrm{K}$ boxes (Parkinson, 1993). The DD and K boxes of 102 regulatory proteins cited in the literature were aligned by hand. Oligonucleotides were designed to match as many proteins as possible. Thus, even with a 384 -fold degeneracy for the DD primer and a 256-fold degeneracy for the $\mathrm{K}$ primer, one could theoretically amplify only $25 \%$ (26 out of 102) of the genes encoding these known proteins. Fig. 1 shows the redundancy of amino acids within conserved stretches of the receiver domain and the sequences of the two degenerate primers. The primers were synthesized in an Oligo 1000 DNA Synthesizer (Beckman).

PCR technique. Amplification was performed in a PerkinElmer Cetus 9600 Thermal Cycler. Chromosomal DNA (250 ng) was used as starting material. Standard Taq polymerase ( 2.5 units), $2 \mathrm{mM}$ each deoxynucleotide triphosphate and $0.3 \mathrm{mM}$ degenerate primers were used. The reaction mixtures were adjusted to a final volume of $100 \mu$ l. They were processed through a three-cycle programme consisting of a $30 \mathrm{~s}$ denaturation period at $94^{\circ} \mathrm{C}$, a $30 \mathrm{~s}$ annealing period at $37^{\circ} \mathrm{C}$ and a $30 \mathrm{~s}$ elongation period at $72{ }^{\circ} \mathrm{C}$ followed by a $30-$ cycle programme consisting of a $30 \mathrm{~s}$ denaturation period at $94^{\circ} \mathrm{C}$, a $30 \mathrm{~s}$ annealing period at $55^{\circ} \mathrm{C}$ and a $30 \mathrm{~s}$ elongation period at $72^{\circ} \mathrm{C}$. 
Cloning of amplified DNA segments. PCR products were precipitated with $6.5 \%(\mathrm{w} / \mathrm{v})$ PEG $/ 1 \mathrm{M} \mathrm{NaCl}$ and digested with EcoRI and $\mathrm{XbaI}$. DNA fragments of interest were separated on a $1.5 \%(\mathrm{w} / \mathrm{v})$ Seakem GTG agarose gel in Tris/acetate buffer, purified and cloned into an EcoRI/XbaIlinearized pBluescript II SK+ vector. E. coli TG1 cells were electroporated with the ligation mixtures. Recombinant clones were used to purify plasmid DNAs.

DNA sequencing. Plasmid DNA for sequencing was prepared as described by Sorokin et al. (1995). PCR sequencing was performed using the Applied Biosystems PRISM Direct and Reverse Sequencing Kit on the Perkin-Elmer Cetus 9600 Thermal Cycler or the Applied Biosystems Catalyst Station. Analysis of nucleotide and amino acid sequences, and searches of sequence homology were carried out on computers using the Genetic Computer Group (GCG) package (Devereux et al., 1984).

DNA sequence accession numbers. GenBank accession numbers used in this study are: U82567 (lbu-4), U82568 (lbu3), U82569 (lbu-1), U82570 (lbu-2), U82571 (atu-7), U82572 (atu-8), U82573 (atu-2), U82574 (atu-6), U82575 (atu-3), U82576 (atu-1), U82577 (atu-5), U82578 (atu-4), U82579 (eco1), U82580 (bsu-2), U82581 (bsu-3) and U82582 (bsu-1).

\section{RESULTS}

\section{Design of the primers}

The amino acid sequence of 102 receiver modules shows a high degree of conservation of specific residues (for the alignment of 49 receiver modules see Pao \& Saier, 1995). Two particularly well conserved domains, approximately 100 aa apart, were selected as the basis of degenerate primer synthesis (Fig. 1). The DNA sequence of the coding strand primer, named the DD primer (384fold degeneracy) was based on a consensus sequence (IVL)V(DE)D (DE) encompassing the DD box of receiver modules (Parkinson, 1993). The DNA sequence of the complementary strand primer, named the $\mathrm{K}$ primer (256-fold degeneracy), corresponded to the consensus sequence $\mathrm{GADD}(\mathrm{YF})$ present in the $\mathrm{K}$ box of receiver modules (Parkinson, 1993). Codon preference was not considered in the primer design, as the purpose was to amplify DNA from various bacterial species. To stabilize the primers after the preliminary rounds of amplification (which were done at a low annealing temperature) and to facilitate further cloning, an additional tail of $9 \mathrm{nt}$ containing an endonuclease restriction site was added at their $5^{\prime}$ end (Compton, 1990). Thus, an EcoRI site was added at the $5^{\prime}$ end of the DD primer and a XbaI site at that of the $\mathrm{K}$ primer.

Specific receiver module fragments amplified with these primers should have a size ranging from 276 to $333 \mathrm{bp}$ encoding 92-111 aa, according to the literature (Stock et al., 1989a; Volz, 1993, 1995; Pao \& Saier, 1995).

\section{Specificity of the DD and K primers in E. coli}

In a preliminary experiment, we verified that the $\mathrm{DD}$ and $\mathrm{K}$ primers made it possible to reliably identify the receiver module of response regulators. For this purpose, we used chromosomal DNA from E. coli strain HVC45 as a template, since over 20 response regulator genes

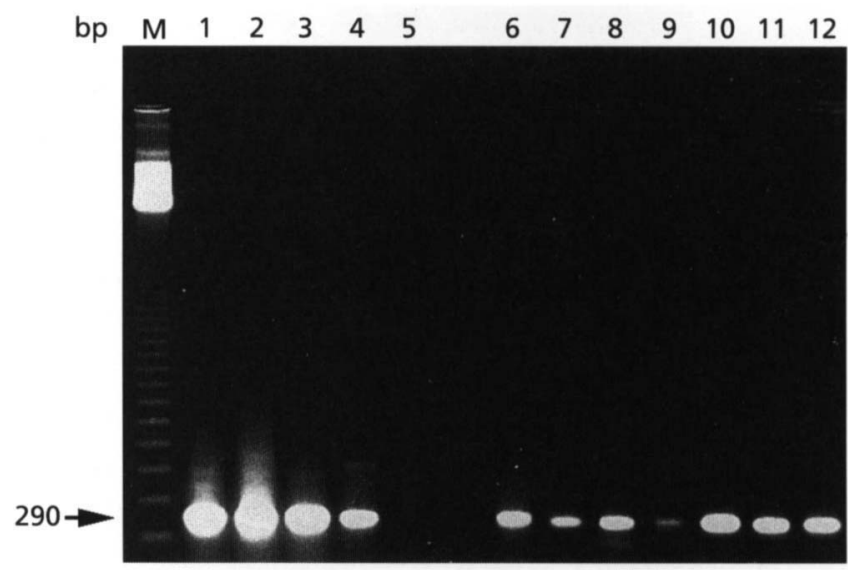

Fig. 2. Ethidium bromide-stained agarose gel of PCR products from Gram-negative and Gram-positive organisms. Chromosomal DNA of the different strains was amplified using PCR with the 24-mer degenerate primers. Lanes 1 to 12 correspond to $10 \mu \mathrm{l}$ of the PCR mixtures with the chromosomal DNA of $E$. coli, $A$. tumefaciens, Erw. amylovora, Pan. citrea, $X$. malvacearum, B. subtilis, C. acetobutylicum, Ent. faecalis, Lb. bulgaricus, Lb. sake, $L$. lactis subsp. lactis and Staph. aureus. Lane $M$ corresponds to the $123 \mathrm{bp}$ DNA ladder (BRL). The position of the $290 \mathrm{bp}$ expected amplified fragment is indicated (arrow).

have been identified in this model Gram-negative bacterium (Nagasawa et al., 1993). DNA sequence data corresponding to these receiver modules indicated that the DD and $K$ primers should match at least ten of them (arcA, phoB, creB, kdpE, pcoR, torR, ompR, basR, baeR, cpxR) (Lee et al., 1990; Dong et al., 1993; Nagasawa et al., 1993; Pao \& Saier, 1995). PCR was performed as described in Methods. PCR products were analysed on a $1.5 \%$ agarose gel. As shown in Fig. 2 (lane 1), a unique and intense band of the expected size (about $290 \mathrm{bp}$ ) was observed. The DNA fragments were purified, cloned into the unique EcoRI/XbaI sites of the pBluescript II SK+ vector and sequenced on both strands.

Analysis of the nucleotide sequence for 35 clones revealed that they corresponded to five different DNA sequences (Fig. 3). Each of the five sequences of the coding strand contained an uninterrupted ORF (Fig. 3). Their size (including the primer consensus sequences) ranged from 276 to $288 \mathrm{bp}$, as expected from the sequence alignments of known receiver modules (Stock et al., 1989a ; Volz, 1993, 1995 ; Pao \& Saier, 1995).

Sequence analysis (using the GenBank database) revealed that fragments of the E. coli ompR, phoB, creB and $c p x R$ genes had been amplified (Wurtzel et al., 1982; Dong et al., 1993; Makino et al., 1986; Amemura et al., 1986). The four corresponding PCR fragments have a nucleotide sequence identical to that published previously (see Table 1). The fifth amplified DNA segment showed high amino acid similarities (over $45 \%$ identity) with receiver modules from E. coli (PcoR) and other Gram-negative bacteria (Pseudomonas syringae CopR 
CheY

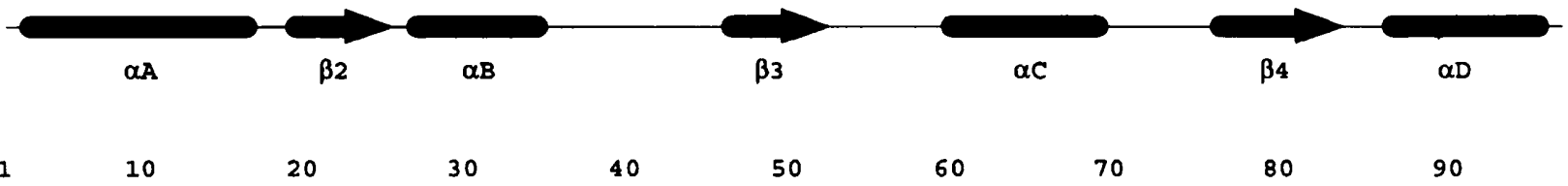

CPXR DRELTSLLKELLEMEGF.NVIVAHDGEQALDLLD . . . . . . DSIDLLLLDVMMPKKNGIDTLKAL. RQTH . .QT . PVIMLTARGSELDRVLGLELG CreB EQGIADTLVYMLQQEGFAVEVFERGLPVLDKARK . . . . . QVPDVMILDVGLPDISGFELCRQL . LALH. . PALPVLFLTARSEEVDRLLGLEIG OMPR DMRLRALLERYLTEQGF. QVRSVANAEQMDRLLT . . . . . RESFHLMVLDLMLPGEDGLSICRRL. RSQS . . NPMPI IMVTAKGEEVDRIVGLEIG PhOB EAPIREMVCFVLEQNGFQPVEAEDYDSAVNQLNE . . . . . PWPDLILLDWMLPGGSGIQFIKHI . KRESMTRDI PVVMLTARGEEEDRVRGLETG ECO-1 EKKTGEYLTKGLTEAGFVVDLADNGLNGYHLAMT . . . . . . GDYDLIILDIMLPDVNGWDIVRML . RSAN . . KGMPILLLTALGTIEHRVKGLELG

AtU- 1 DHVLGEALRDHVAAAGHAVDWFKLLDDATAATLT. . . . . . MTYGLILLDMRLPDGDGITLLQSL. RNRD. .DSTPVI ILTAHDQVSDRIAGLNAG AtU-2 DRNILTSVSIALEAEVHRVETYTDGASALDGLIA . . . . RPPQLAIFDIKMPRMDGMELLRRL . RQ.K. . SDIPVIFLTSKDEEIDELFGLKMG AtU-3 DPEIRTLLAKYLGSQGF . RVSMAADRXXFEDRFA . . . . CSDPDLIVLDVMLPDGSGLDICRDL. QGRR. . RGTPVILLTALKEDVDRIVGLEIG Atu-4 EKEMADALSTTLGKOGIVIDHTMRLGDAMELARX . . . . . . IAYDAILLDRRLPDGEGLTFI PKL. RRAG . . IDTPI ILLTAMNEPEER IEGLNGG Atu-5 DPRVADFLERGLRAEGYSVXXPVNGPTGIARAHELWQEWRSTGANGAVLLDVMLPVISGSDVCQTL. RARG . . ISAPILMLTALGSVNDRISGLRMG AtU-6 EPEMARALLEALRRRDVLADHVRTIADADALARD . . . . . GSYDVLVLDRRLPDGEGLNLVSSL. RKAR. . HSVPILVLTALGSVDHRVDGLDAG AtU-7 DANLNRQLTDALKGAGYVVDQAFDGEEGHYLGDT . . . . EPYDAIVLDIGLPQMDGITVVEKW. RAAG . . KAMPVLILTARDRWSDKVAGIDAG AtU - 8 DQVLSEGLCALLRGSVYAVDVVSDGASATRRXAA . . . . . ENFDLVILDLNLPEMDGIEVLRSM. RSRQ . DKAAVLILTARGTPEEKVKGLDLG

PhOP DHSISEMVDHYLTKEGF.GIVHAFDGEEGIRLFQ . . . . QGSYDLVLLDIMLPKLNGMDFLKII . REKS . NI . PVLMISAKDGDVDKALGLGFG OrfX EKPIADILEFNLRKEGY. EVHCTHDGNEAVEMVE . . . . . ELQPDLILLDIMLPNKDGVEVCREV.RKKY..DM. PIIMLTAKDSEIDKVIGLEIG BSU- 1 DESLFHEI KERLTGWSYDVYGIQDFSQVLQEFAA . . . . . . VNPDCVIIDVQLPKFDGFHWCRLI. RSRS . . NVPILFLSSRDHPADMVMSMQLG BSU-2 DPMVQEVNKDI ITTVKGVTVCATAGNGEEGMKLI . . . . . KEEQPDLVILDVYMPKKDGIKTLQEIRKQKL . . EVDVIVVS . AAKDKETISLMLQNG BSU-3 EKAIVDMIKRVLEKEGYRNILDAASAEEAI PVVK . . . . . ANKVDLIVLDVMMGGMSGFEACTLI . REYS . DA . PIFFLTARSSDADKLSGFAVG

Lbu- 1 EAQLNRVLTVAMQKSGYDVDSVFNGQEAVDAVKK. . . . . . HPYDVI IMDIMMPVKNGLDAVKEI .RSTG . DKTYIMMLTAKSEIDDKVTGLDVG Lbu-2 D. EIVELLSIYLKNEGY . EPIAAYNGKEALTKLS . . . . . TTPDIALMILDVMMPNMSGIDVVKEV. RKDS . . DI . PI I IVSAKTGDMDKIQGLITG Lbu-3 E.SIREIEMYTLESMNFKVRGFEDGQSFFKALDN . . . . . SRPDLVILDLMLPDEDGSEILHRL. RSTSATEDLPVI IASAKTAEYDKVKNLDSG Lbu-4 DKSVSQMMELFFKKEGW. EQVSAYDGEEAVE IFQ . . . . THPRDFDI ITLDLNLPKKDGIQVAKEI . RRIS . ETVPI IMLTARDRNSDQVLGLGVG

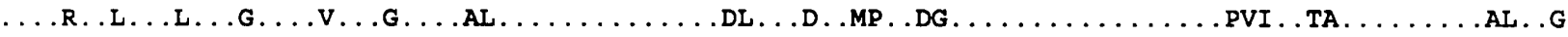

Fig. 3. Comparison of the deduced amino acid sequences of the 22 response regulator internal fragments cloned by PCR from the genomes of $E$. coli (Eco), A. tumefaciens (Atu), B. subtilis (Bsu) and Lb. bulgaricus (Lbu). Sequences corresponding to the degenerate primers can be inaccurate and are therefore not shown. Sequences were aligned using the GCG PILEUP program. Consensus amino acid residues (Pao \& Saier, 1995) are indicated in the bottom line. The fully conserved aspartate is indicated by an asterisk above the multiple alignment. The secondary structure of $E$. coli CheY is indicated above the multiple alignment, with arrows representing $\beta$-strands, cylinders representing $\alpha$-helices and lines representing loop regions (Stock et al., 1989b).

and Fremyella diplosiphon $\mathrm{RcaC}$ ) (Table 1). These similarities increased to over $80 \%$ when allowances were made for conservative amino acid substitutions which clearly indicates that this fragment originates from a response regulator gene. However, it was not identical to any of the previously known genes and was designated eco-1. The highest similarity was obtained with the E. coli plasmid pRJ1004 pcoR gene product $(54.6 \%$ identity) involved in copper resistance (Lee et al., 1990). Mutagenesis of this newly identified gene should make it possible to determine its function and the genes under its control. These results show that PCR was successful in isolating various response regulator genes from E. coli.

\section{Extension of the PCR method to other bacterial species}

We used the $\mathrm{DD}$ and $\mathrm{K}$ primers to isolate response regulator genes in various bacterial species. Total DNA from four Gram-negative bacteria (A. tumefaciens, Erw. amylovora, Pan. citrea, X. malvacearum) and seven Gram-positive bacteria (B. subtilis, C. acetobutylicum, Ent. faecalis, Lb. bulgaricus, Lb. sake, L. lactis subsp. lactis and Staph. aureus) was used as template. For each strain, an amplified DNA fragment of the expected size (approximately $290 \mathrm{bp}$ ) was generated (Fig. 2, lanes 2-12). PCR was internally controlled with $E$. coli total DNA (Fig. 2, lane 1). For X. malvacearum, the amplified band was particularly weak which may indicate that the $\mathrm{DD}$ and $\mathrm{K}$ primers were not adapted to this species. For Pan. citrea and Ent. faecalis, faint extra bands were also visible. They probably resulted from a non-specific amplification and were not analysed further.

PCR products from A. tumefaciens, B. subtilis and $L b$. bulgaricus were purified, cloned and sequenced as described above. Sequence comparison of 30 independent clones from A. tumefaciens, 48 from $B$. subtilis and 30 from $L b$. bulgaricus showed that they corresponded to 20,15 and 9 different DNA segments, respectively (data not shown). Analysis of their deduced amino acid sequences revealed that eight $A$. tumefaciens, five $B$. 
Table 1. Comparison of cloned receiver modules with proteins in the GenBank database

\begin{tabular}{|c|c|c|c|c|c|c|c|}
\hline \multirow[t]{2}{*}{ Organism } & \multirow[t]{2}{*}{ ORF } & \multirow{2}{*}{$\begin{array}{l}\text { Obtention } \\
\text { frequency }\end{array}$} & \multicolumn{2}{|l|}{ Best matches } & \multirow{2}{*}{$\begin{array}{c}\text { Identity } \\
(\%)\end{array}$} & \multirow{2}{*}{$\begin{array}{c}\text { Similarity } \\
(\%)\end{array}$} & \multirow{2}{*}{$\begin{array}{c}\text { GenBank } \\
\text { accession no. }\end{array}$} \\
\hline & & & Organism & Protein* & & & \\
\hline \multirow[t]{7}{*}{ E. coli } & $o m p R$ & $17 / 35$ & E. coli & OmpR & 100 & & J01656 \\
\hline & $c p x R$ & $4 / 35$ & E. coli & CpxR & 100 & & L14579 \\
\hline & phoB & $7 / 35$ & E. coli & PhoB & 100 & & X04026 \\
\hline & $\mathrm{creB}$ & $5 / 35$ & E. coli & CreB & 100 & & M13608 \\
\hline & $e c o-1$ & $2 / 35$ & Pseudomonas syringae & CopR & $52 \cdot 6$ & $87 \cdot 6$ & L05176 \\
\hline & & & E. coli plasmid pRJ1004 & PcoR & $54 \cdot 6$ & $85 \cdot 6$ & X83541 \\
\hline & & & Fremyella diplosiphon & $\mathrm{RcaC}$ & $45 \cdot 8$ & $80 \cdot 4$ & M95680 \\
\hline \multirow[t]{24}{*}{ A. tumefaciens } & atu-1 & $2 / 30$ & E. coli $\mathrm{K}-12$ & $\mathrm{HP}$ & $38 \cdot 1$ & $82 \cdot 5$ & U28377 \\
\hline & & & Salmonella typhimurium & PmrA & $43 \cdot 3$ & $77 \cdot 3$ & L13395 \\
\hline & & & E. coli & BasR & $42 \cdot 3$ & $78 \cdot 3$ & D14055 \\
\hline & atu-2 & $1 / 30$ & Agrobacterium tumefaciens NT-1 & ChvI & $89 \cdot 6$ & $96 \cdot 8$ & L19166 \\
\hline & & & Bacillus subtilis & $\mathrm{HP}$ & $41 \cdot 7$ & $83 \cdot 3$ & D26185 \\
\hline & & & Mycobacterium tuberculosis & MtrA & $36 \cdot 5$ & $84 \cdot 3$ & U01971 \\
\hline & atu-3 & $9 / 30$ & Sal. typhimurium & OmpR & $47 \cdot 4$ & $87 \cdot 6$ & $\mathrm{X} 12374$ \\
\hline & & & E. coli & OmpR & $47 \cdot 4$ & $88 \cdot 6$ & J01656 \\
\hline & & & Xenorhabdus nematophilus & OmpR & $43 \cdot 3$ & $85 \cdot 6$ & U07746 \\
\hline & $a t u-4$ & $1 / 30$ & Brucella melitensis & PhoP & $33 \cdot 0$ & $78 \cdot 3$ & X87324 \\
\hline & & & F. diplosiphon & $\mathrm{RcaC}$ & $31 \cdot 2$ & $79 \cdot 4$ & M95680 \\
\hline & & & Streptomyces lividans & CutR & $37 \cdot 1$ & $76 \cdot 3$ & X58793 \\
\hline & $a t u-5$ & $1 / 30$ & E. coli plasmid pRJ1004 & PcoR & $40 \cdot 5$ & $79 \cdot 0$ & X83541 \\
\hline & & & B. subtilis & $\mathrm{HP}$ & $41 \cdot 0$ & $74 \cdot 3$ & D26185 \\
\hline & & & M. tuberculosis & MtrA & $41 \cdot 0$ & $77 \cdot 1$ & U01971 \\
\hline & $a t u-6$ & $2 / 30$ & P. syringae & CopR & $42 \cdot 3$ & $80 \cdot 4$ & L05176 \\
\hline & & & $\mathrm{Br}$. melitensis & PhoP & $36 \cdot 1$ & $81 \cdot 4$ & X87324 \\
\hline & & & Sal. typhimurium & OmpR & $39 \cdot 8$ & $77 \cdot 3$ & $\mathrm{X} 12374$ \\
\hline & atu-7 & $1 / 30$ & $\mathrm{Br}$. melitensis & PhoP & $77 \cdot 3$ & $95 \cdot 9$ & X87324 \\
\hline & & & E. coli & PhoP & $41 \cdot 2$ & $84 \cdot 5$ & D90393 \\
\hline & & & F. diplosiphon & RcaC & $49 \cdot 5$ & $81 \cdot 4$ & M95680 \\
\hline & $a t u-8$ & $1 / 30$ & E. coli & BasR & $44 \cdot 3$ & $81 \cdot 4$ & D14055 \\
\hline & & & E. coli $\mathrm{K}-12$ & HP & $44 \cdot 3$ & $84 \cdot 4$ & U14003 \\
\hline & & & Sal. typhimurium & PmrA & $41 \cdot 2$ & $82 \cdot 5$ & L13395 \\
\hline \multirow[t]{11}{*}{ B. subtilis } & $\operatorname{orf} X$ & $13 / 48$ & B. subtilis & $\mathrm{HP}$ & 100 & & D26185 \\
\hline & phoP & $4 / 48$ & B. subtilis & PhoP & 100 & & D30808 \\
\hline & $b s u-1$ & $2 / 48$ & B. subtilis & $\mathrm{HP}$ & $38 \cdot 3$ & $75 \cdot 0$ & D14399 \\
\hline & & & Rhodella violacea plastid & OmpR & $35 \cdot 1$ & $75 \cdot 0$ & U01831 \\
\hline & & & $P$. aerugineum & OmpR & $35 \cdot 1$ & $76 \cdot 0$ & X62579 \\
\hline & $b s u-2$ & $9 / 48$ & B. megaterium & $\mathrm{HP}$ & $56 \cdot 6$ & $88 \cdot 9$ & D90043 \\
\hline & & & E. coli & NarL & $35 \cdot 4$ & $84 \cdot 8$ & $\mathrm{X} 13360$ \\
\hline & & & E. coli $\mathrm{K}-12$ & $\mathrm{HP}$ & $36 \cdot 6$ & $80 \cdot 8$ & U14003 \\
\hline & $b s u-3$ & $4 / 48$ & B. subtilis & $\mathrm{HP}$ & $45 \cdot 4$ & $80 \cdot 4$ & D26185 \\
\hline & & & B. subtilis & $\mathrm{HP}$ & $44 \cdot 3$ & $82 \cdot 5$ & L09228 \\
\hline & & & Porphyridium aerugineum & OmpR & $41 \cdot 2$ & $81 \cdot 4$ & $\mathrm{X} 62579$ \\
\hline \multirow[t]{12}{*}{ L. bulgaricus } & $l b u-1$ & $1 / 30$ & Br. melitensis & PhoP & $41 \cdot 2$ & $81 \cdot 4$ & X87324 \\
\hline & & & Sal. typhimurium & TctD & $38 \cdot 1$ & $84 \cdot 5$ & M28368 \\
\hline & & & Haemophilus influenzae $\mathrm{Rd}$ & BasR & $33 \cdot 0$ & $83 \cdot 5$ & L 46338 \\
\hline & $l b u-2$ & $6 / 30$ & Enterococcus faecium & VanR & $44 \cdot 3$ & $88 \cdot 6$ & M84146 \\
\hline & & & H. influenzae $\mathrm{Rd}$ & $\mathrm{HP}$ & $45 \cdot 8$ & $83 \cdot 3$ & L45475 \\
\hline & & & M. tuberculosis & MtrA & $44 \cdot 3$ & $84 \cdot 5$ & U01971 \\
\hline & $l b u-3$ & $2 / 30$ & E. coli & PhoB & $41 \cdot 4$ & $82 \cdot 8$ & X04026 \\
\hline & & & Shigella flexneri & PhoB & $41 \cdot 4$ & $82 \cdot 8$ & X81000 \\
\hline & & & Yersinia pseudotuberculosis & PhoB & $33 \cdot 7$ & $82 \cdot 8$ & X66585 \\
\hline & $l b u-4$ & $1 / 30$ & Br. melitensis & PhoP & $43 \cdot 4$ & $79 \cdot 8$ & X87324 \\
\hline & & & R. violacea plastid & OmpR & $44 \cdot 4$ & $79 \cdot 8$ & U01831 \\
\hline & & & Ent. faecium & VanR & $37 \cdot 4$ & $83 \cdot 8$ & M84146 \\
\hline
\end{tabular}

\footnotetext{
* HP, hypothetical protein.
} 
subtilis and four Lb. bulgaricus segments exhibited striking similarities with the consensus sequence of receiver modules (Fig. 3). The amino acid sequence of the ORFs was compared with internal sequences of receiver domains from the 102 bacterial response regulators used. The multiple alignment of our 17 sequences ( 22 including those from E. coli) together with the consensus sequence defined by Pao \& Saier (1995) from 49 receiver modules showed that they contain most of the highly conserved residues (Fig. 3). The leucine (alignment position 12) and the glycine (alignment position 16) residues are present in most of the sequences. Close to the centre, an internal signature of receiver modules is found: an invariant aspartate residue (alignment position 51) which presumably serves as the site of transphosphorylation by the sensor kinase (Parkinson, 1993). The aspartate residue is almost always preceded by four strongly hydrophobic, aliphatic residues ( $\mathrm{L}, \mathrm{V}$ and $\mathrm{I})$. These five amino acids are expected to constitute the third $\beta$ strand of the receiver module (Stock et al., 1995) (Fig. 3). Other invariant residues found in most of the sequences are proline (alignment position 55) and glycine (alignment position 59). Near the end of these domains, a proline residue is found (alignment position 77) followed by four strongly hydrophobic, aliphatic residues (L, V and I) (alignment positions 78-81), presumably constituting part of the receiver module fourth $\beta$ strand (Stock et al., 1995) (Fig. 3 ). The last amino acids of striking conservation are the TA motif (alignment positions 82-83) and the leucine residue (alignment position 94), three residues before the consensus GADD(YF) which served as the complementary strand primer. They also possessed the alternating $\alpha$-helix and $\beta$-strand segments found in all receiver modules (Fig. 3) (Stock et al., 1995) and characterized by $\mathrm{X}$-ray studies of the Salmonella typhimurium (Stock $e t$ al., 1989b) and E. coli (Volz \& Matsumura, 1991) CheY proteins. These results provided strong evidence that these DNA segments, amplified by the primer set, encode receiver domains of response regulator genes or of unorthodox sensor genes. Moreover, they showed a high level of homology with numerous response regulator receiver modules in the sequence databases (see Table 1).

One fragment from A. tumefaciens (designated atu-2) most probably comes from the chvI gene (Charles $\&$ Nester, 1993), although the amino acid sequence was not perfectly identical ( $89.6 \%$ identity). The $c h v I$ gene was originally isolated from A. tumefaciens strain NT1 which appears to be slightly different from $A$. tumefaciens strain LBA4301 used in this study. The amino acid sequence of atu-7 closely resembles that of Brucella melitensis phoP (77.3\% identity) (N. Dorrell, GenBank no. X87324). All other A. tumefaciens fragments (atu-1, atu-3, atu-4, atu-5, atu-6 and atu-8) encode new regulators since their level of identity with known sequences is rather low $(<50 \%)$ and their functions remain to be determined. For B. subtilis, fragments from two already sequenced response regulator genes have been amplified. One comes from the
phoP gene (Ogawa et al., 1995) while the second comes from a gene whose function has not yet been elucidated (Ogasawara \& Yoshikawa, 1992). The other three fragments corresponded to previously unknown response regulators, and were designated $b s u-1$ to $b s u-3$. We found four fragments in $L b$. bulgaricus encoding new response regulator receiver modules $(\mathrm{lbu}-1$ to $\mathrm{lbu}$ 4).

\section{DISCUSSION}

We have developed a PCR-based method which allows a rapid and accurate isolation of internal fragments of genes encoding response regulators from a wide range of bacteria. A single PCR performed with a set of two degenerate oligonucleotide primers complementary to the well conserved DD and $\mathrm{K}$ boxes present at each end of the receiver module domain of response regulators (Parkinson, 1993) is sufficient to amplify them with a rather high specificity: from 30 to $100 \%$ of the isolated clones correspond to response regulator genes. PCR products of the expected size were obtained from a dozen different species, including genera as distantly related to each other as Agrobacterium, Bacillus and Lactococcus. This was achieved by using degenerate primers based on five consecutive amino acid residues and a low annealing temperature, i.e. $37^{\circ} \mathrm{C}$, during the first cycles of amplification. Various other primer pairs based on only three consecutive amino acid residues were initially tried without convincing results (data not shown). Despite what has been reported elsewhere (Compton, 1990), it seems that, in this particular case, degenerate primers must be long enough to produce a specific amplification. Unexpected PCR products (12 out of 30 from A. tumefaciens, 12 out of 48 from $B$. subtilis and 20 out of 30 from Lb. bulgaricus) were also isolated. They reflect the power and the limitations of the method used. Lower primer degeneracy would theoretically reduce the aspecific background but only allow the cloning of a few receiver modules encoding fragments, whereas higher primer degeneracy would allow us to isolate a larger number of fragments but associated with a higher background.

Sequence analysis revealed that $o m p R$, $p h o B, c r e B$ and $c p x R$ gene fragments have been amplified from E. coli total DNA, and that $p h o P$ and an uncharacterized ORF, orf $X$, have been amplified from $B$. subtilis, as well as the $A$. tumefaciens NT-1 chvI homologous gene from $A$. tumefaciens LBA4301. Most probably, the A. tumefaciens phoP gene was identified since the sequence of the isolated fragment showed a very strong identity $(>75 \%$ ) with other bacterial phoP genes.

Fourteen receiver modules identified in this study (one from $E$. coli, three from B. subtilis, four from $L b$. bulgaricus and six from A. tumefaciens) clearly come from response regulator genes or might be part of hybrid or unorthodox sensors. However, they did not seem to correspond to any known genes since their level of similarity was rather low ( $\leqslant 50 \%$ identity). Receiver 
module domains were particularly well conserved even if they underwent selective shuffling during evolution, due to intragenic splicing and fusion (Pao \& Saier, 1995). Therefore, it is not possible to extrapolate functions of the entire proteins from these short sequences. Full-length genes are needed as well as the determination of the gene border sequences that would reveal whether a corresponding sensor kinase is linked to a particular response regulator. Constructing mutants will be necessary to investigate their phenotypes and physiological properties, thus to identify the pathway in which they are involved.

Most members of the sensor/regulator family have been found in a fortuitous manner from nucleotide sequence analyses of certain regulatory genes. To extend the list of sensor/regulator proteins, a complementation strategy was used recently. This strategy is based on the hypothesis that a response regulator is able to acquire a phosphoryl group not only from its cognate sensory kinase but also from heterologous kinases, the process designated crosstalk (Stock et al., 1989a ; Wanner, 1992). New sensor genes in E. coli (Nagasawa et al., 1992, 1993) and in Synechococcus (Aiba et al., 1993) were isolated by complementing the sensor-kinase-defective strains of E. coli (a mutational lesion in envZ or in phoR/creC was used) (Nagasawa et al., 1992, 1993; Aiba et al., 1993). Compared to complementation, PCR with degenerate primers is much more random since receiver modules are highly conserved among bacteria. In our experiments, by using a single set of primers, we succeeded in directly cloning 22 different response regulator genes from a limited number of clones analysed $(<150)$. It is legitimate to envisage that other regulators could be easily obtained by screening more clones. Recently, the PCR-based approach has been used to clone histidine kinases (Bayles, 1993; Lee \& Stock, 1996), $\sigma^{54}$-dependent regulators (Kaufman \& Nixon, 1996) or recA genes (Duwat et al., 1992). Furthermore, an almost identical approach was previously used to isolate response regulator genes from a number of pathogenic bacteria but with less convincing results (Wren et al., 1992).

The degenerate primers used in this study were designed from the most conserved amino acid residues, essentially from Gram-negative bacteria genes. They allowed amplification of Gram-positive internal receiver domains but the number of different sequences obtained was smaller than from Gram-negative organisms. Such a difference may be a reflection of the number of twocomponent transduction systems that are present in a particular bacterial genome, known to vary from one species to another. However, it is conceivable that the primers may preferentially match DNAs from related bacterial species. It should be possible to adapt the primer design so that further response regulators can be amplified. In particular, a closer look at the 102 receiver modules of known bacterial response regulators showed that the amino acid sequence $\mathrm{GADD}(\mathrm{YF})$ in the $\mathrm{K}$ box, which was used to design the $\mathrm{K}$ primer, is mainly found in Class 2 proteins (OmpR, PhoP, PhoB, CreB, ArcA,
BaeR, KdpE, BasR, etc.) according to the Pao \& Saier (1995) classification based on phylogenetic relatedness of the proteins receiver and effector domains. As a consequence, the majority of sequences isolated in this study (Table 1) seem to belong to this class of response regulators which function as transcriptional activators of $\sigma^{70}$-dependent promoters. Slight alterations in the $\mathrm{K}$ box primer should allow the amplification of the other two major response regulator classes (Class 1 proteins which usually activate transcription of $\sigma^{54}$-dependent promoters and Class 3 proteins which function by an uncharacterized mechanism involving more than one $\sigma$ factor; Pao \& Saier, 1995).

In conclusion, this amplification strategy made it possible to identify numerous Gram-positive and Gramnegative response regulator receiver domains. We consider it as the most reliable for extending the list of the sensor/regulator families in bacteria, especially for those which are difficult to find by the usual genetic studies.

\section{ACKNOWLEDGEMENTS}

We are grateful to F. Chedin and C. Bruand for their useful suggestions during this work and to $\mathrm{C}$. Anagnostopoulos for critical reading of the manuscript. We thank C. I. Kado, C. Pujol, P. Duwat and M. C. Chopin for providing us with chromosomal DNAs and strains.

\section{REFERENCES}

Aiba, H., Nagaya, M. \& Mizuno, T. (1993). Sensor and regulator proteins from the cyanobacterium Synechococcus species PCC7942 that belong to the bacterial signal-transduction protein families: implication in the adaptative response to phosphate limitation. Mol Microbiol 8, 81-91.

Alex, L. A. \& Simon, M. I. (1994). Protein histidine kinases and signal transduction in prokaryotes and eukaryotes. Trends Genet 10, 133-139.

Amemura, M., Makino, K., Shinagawa, H. \& Nakata, A. (1986). Nucleotide sequence of the phoM region of Escherichia coli: four open reading frames may constitute an operon. J Bacteriol 168, 294-302.

Appleby, J. L., Parkinson, J. S. \& Bourret, R. B. (1996). Signal transduction via the multi-step phosphorelay: not necessarily a road less traveled. Cell $86,845-848$.

Bayles, K. W. (1993). The use of degenerate, sensor gene-specific, oligodeoxyribonucleotide primers to amplify DNA fragments from Staphylococcus aureus. Gene 123, 99-103.

Bult, C. J. \& others (1996). Complete genome sequence of the methanogenic archaeon, Methanococcus jannaschii. Science 273, 1058-1073.

Chang, C. \& Meyerowitz, E. M. (1994). Eukaryotes have 'twocomponent' signal transducers. Res Microbiol 145, 481-486.

Charles, T. C. \& Nester, E. W. (1993). A chromosomally encoded two-component sensory transduction system is required for virulence of Agrobacterium tumefaciens. J Bacteriol 175, $6614-6625$.

Compton, T. (1990). Degenerate primers for PCR amplification. In PCR Protocols: a Guide to Methods and Applications, pp. 39-45. Edited by M. A. Innis, D. H. Gelfand, J. J. Sninsky \& T. J. White. London: Academic Press. 
Devereux, J., Haeberli, P. \& Smithies, O. (1984). A comprehensive set of sequence analysis programs for the VAX. Nucleic Acids Res 12, 387-395.

Dong, J., luchi, S., Kwan, H. S., Lu, Z. \& Lin, E. C. (1993). The deduced amino-acid sequence of the cloned $c p x R$ gene suggests the protein is the cognate regulator for the membrane sensor CpxA in a two-component signal transduction system of Escherichia coli. Gene 13, 227-230.

Duwat, P., Ehrlich, S. D. \& Gruss, A. (1992). A general method for cloning recA genes of Gram-positive bacteria by polymerase chain reaction. J Bacteriol 174, 5171-5175.

Falke, J. J., Blair, D. F., Silhavy, T. J. \& Schmitt, R. (1995). BLAST 1995: International conference on bacterial locomotion and signal transduction. Mol Microbiol 16, 1037-1050.

Fleischmann, R. D. \& others (1995). Whole-genome random sequencing and assembly of Haemophilus influenzae Rd. Science 269, 496-512.

Hoch, J. A. \& Silhavy, T. J. (editors) (1995). Two-component Signal Transduction. Washington, DC: American Society for Microbiology.

Kado, C. I., Heskett, M. G. \& Langley, R. A. (1972). Studies on Agrobacterium tumefaciens. Characterization of strains 1D135 and B6, and analysis of the bacterial chromosome, transfer RNA, and ribosomes for tumor inducing ability. Physiol Plant Pathol 2, 47-59.

Kaufman, B. I. \& Nixon, B. T. (1996). Use of PCR to isolate genes encoding $\sigma^{54}$-dependent activators from diverse bacteria. $J$ Bacteriol 178, 3967-3970.

Lee, B. T. O., Brown, N. L., Rogers, S., Bergemann, A., Camakaris, J. \& Rouch, D. A. (1990). Bacterial response to copper in the environment: copper resistance in Escherichia coli as a model system. NATO ASI Ser Ser G Ecol Sci 23, 625-632.

Lee, P.-J. \& Stock, A. M. (1996). Characterization of the genes and proteins of a two-component system from the hyperthermophilic bacterium Thermotoga maritima. J Bacteriol 178, 5579-5585.

Makino, K., Shinagawa, H., Amemura, M. \& Nakata, A. (1986). Nucleotide sequence of the $p h o B$ gene, the positive regulatory gene for the phosphate regulon of Escherichia coli K12.J Mol Biol 190, 37-44.

Nagasawa, S., Tokishita, S., Aiba, A. \& Mizuno, T. (1992). A novel sensor-regulator protein that belongs to the homologous family of signal-transduction proteins involved in adaptative responses in Escherichia coli. Mol Microbiol 6, 799-807.

Nagasawa, S., Ishige, K. \& Mizuno, T. (1993). Novel members of the two-component signal tranduction genes in Escherichia coli. $J$ Biochem 114, 350-357.

Ogasawara, N. \& Yoshikawa, H. (1992). Genes and their organisation in the replication origin region of the bacterial chromosome. Mol Microbiol 6, 629-634.

Ogawa, K., Akagawa, E., Nakamura, K. \& Yamane, K. (1995). Determination of a 21548 bp nucleotide sequence around the $24^{\circ}$ region of the Bacillus subtilis chromosome. Microbiology 141, 269-275.
Pao, G. M. \& Saier, M. H., Jr (1995). Response regulators of bacterial signal transduction systems: selective domain shuffling during evolution. J Mol Evol 40, 136-154.

Parkinson, J. S. (1993). Signal transduction schemes of bacteria. Cell 73, 857-871.

Parkinson, J. S. \& Kofoid, E. C. (1992). Communication modules in bacterial signalling proteins. Annu Rev Genet 26, 71-112.

Sambrook, J., Fritsch, E. F. \& Maniatis, T. (1989). Molecular Cloning: a Laboratory Manual, 2nd edn. Cold Spring Harbor, NY: Cold Spring Harbor Laboratory.

Sorokin, A., Serror, P., Pujic, P., Azevedo, V. \& Ehrlich, S. D. (1995). The Bacillus subtilis chromosome region encoding homologues of the Escherichia coli mss $A$ and $r p s A$ gene products. Microbiology 141, 311-319.

Stock, J. B., Ninfa, A. D. \& Stock, A. M. (1989a). Protein phosphorylation and regulation of adaptive responses in bacteria. Microbiol Rev 53, 450-490.

Stock, A. M., Mottonen, J. M., Stock, J. B. \& Schutt, C. E. (1989b). Three-dimensional structure of CheY, the response regulator of bacterial chemotaxis. Nature 337, 745-749.

Stock, J. B., Stock, A. M. \& Mottonen, J. M. (1990). Signal transduction in bacteria. Nature 344, 395-400.

Stock, J. B., Surette, M. G., Levit, M. \& Stock, A. M. (1995). Twocomponent signal transduction systems: structure-function relationships and mechanisms of catalysis. In Two-component Signal Transduction, pp. 25-51. Edited by J. A. Hoch \& T. J. Silhavy. Washington, DC: American Society for Microbiology.

Volz, K. (1993). Structural conservation among the CheY superfamily. Biochemistry 32, 11741-11753.

Volz, K. (1995). Structural and functional conservation in response regulators. In Two-component Signal Transduction, pp. 53-64. Edited by J. A. Hoch \& T. J. Silhavy. Washington, DC: American Society for Microbiology.

Volz, K. \& Matsumura, P. (1991). Crystal structure of Escherichia coli CheY refined at $1.7 \AA$ resolution. $J$ Biol Chem 266, 15511-15519.

Wanner, B. L. (1992). Is cross regulation by phosphorylation of two-component response regulator proteins important in bacteria? J Bacteriol 174, 2053-2058.

Wren, B. W., Colby, S. M., Cubberley, R. R. \& Pallen, M. J. (1992). Degenerate PCR primers for the amplification of fragments from genes encoding response regulators from a range of pathogenic bacteria. FEMS Microbiol Lett 78, 287-291.

Wurtzel, E. T., Chou, M. Y. \& Inouye, M. (1982). Osmoregulation of gene expression. I. DNA sequence of the $m p R$ gene of the $o m p B$ operon of Escherichia coli and characterization of its gene product. J Biol Chem 257, 13685-13691.

Received 7 October 1996; revised 3 January 1997; accepted 16 January 1997. 